\title{
CHANGES, PROBLEMS, AND CHALLENGES OF PASSENGER RAILWAY TRANSPORT IN SLOVAKIA
}

\author{
Daniel Michniak* \\ * Geografický ústav SAV, Štefánikova 49, 81473 Bratislava, geogmich@savba.sk
}

\begin{abstract}
Changes, problems, and challenges of passenger railway transport in Slovakia
The passenger railway transport system in Slovakia, during the last almost thirty years, has undergone many changes and it has faced many problems and new challenges. The change of the socio-economic system, the splitting of Czechoslovakia, the process of accession to the EU and membership of Slovakia have influenced transport system in Slovakia. The main aim of this article is to identify main changes, problems and challenges of passenger railway transport in Slovakia after 1989. Attention is paid to the changing position of railway transport in the transport of persons in Slovakia. Article is also focused on the changes of organisation of railway transport in Slovakia and its deregulation, liberalisation, and starting of competition in passenger railway transport with the example of comparison of the operation of the state and the private carriers. The specific governmental measure, a zero-fare public railway transport services for selected groups of passengers, has significantly influenced a passenger railway transport in Slovakia since 2014.
\end{abstract}

Key words: passenger railway transport, the EU transport policy, transport market liberalisation, zero-fare public railway transport services, Slovakia

\section{INTRODUCTION}

During the last three decades transport system in Slovakia has undergone many substantial changes. Till 1989 it had been a part of the transport system of Czechoslovakia under the conditions of the socialist state. Countries of Central and Eastern Europe inherited many problems from the communist period, e.g. poor infrastructural maintenances, inferior technology, organisational and structural obstacles and bottlenecks, neglect of human resources and environmental consideration, imbalanced investments and others (Hall 1993). After the change of regime, the transformation of transport system started, but the splitting of Czechoslovakia since the beginning of 1993 has influenced it. Slovakia had to transform its own transport system to different social, economic and political conditions. Since 1998, when the political orientation of Slovakia to the entry to the European Union was clearly declared, the transport policy of the EU has significantly influenced the transport system in Slovakia. According to Pucher and Buehler (2005) transport policies in many formerly socialist countries in Central and Eastern Europe have becoming increasingly like the policies of Western European countries, because they had been an essential part of Europe for many centuries, and their link to Western Europe had been interrupted only for more than four decades of socialism after World War II.

Transport policy is one of the European Union's (EU) foremost common policies that has been focused on removing borders between the Member States and thus contributing to the free movement of individuals and goods. Its principal aims are to complete the internal market, ensure sustainable development, extend transport networks throughout Europe, maximise the use of space, enhance safety and promote international cooperation. 
In September 2001, the European Commission issued a common transport policy in the White Paper "European Transport Policy for 2010 - Time to decide" (European Commission 2001), where also the problems and challenges of the European transport policy in relation to the EU enlargement in a direction to the East are analysed. According to the European Commission White Paper "Roadmap to a Single European Transport Area - Towards a competitive and resource efficient transport system" (European Commission 2011), transport is a key element for the economy and society. Mobility is important for the internal market and inhabitants because of possibility of free travel. Transport has a global character, and its effective operation requires international cooperation with the aim to create a Single European Transport Area. The transport system of Slovakia should be integrated into this European system.

European transport policy places emphasis, among others, on the higher use of environmentally friendly types of transport, in particular, railway transport. The National Regional Development Strategy of the Slovak Republic (MPaRV SR 2010) also points to the importance of railway as one of the environmentally friendly transport modes (together with water transport, combined transport, and cycling). The White Paper (European Commission 2011) also stresses the importance of railway transport, and other mass (public) transport means in mediumdistance passenger transport and as a part of the effective basic network for multimodal transport between cities.

The internal market for railway services is, according to the White Paper (European Commission 2011), the area where bottlenecks are still most evident and which must be completed as a priority to achieve a Single European Railway Area. This includes the abolishment of technical, administrative and legal obstacles which still impede entry to national railway markets. One of the initiatives is to open the domestic railway passengers market to competition, including the mandatory award of public service contracts under competitive tendering. Another initiative is to ensure effective and non-discriminatory access to railway infrastructure, including rail-related services, in particular through structural separation between infrastructure management and service provision.

The main aim of the article is to identify problems and challenges of passenger railway transport in Slovakia after 1989 and point to their spatial perspective. The article is organised as follows. In the beginning, basic facts concerning railway network are introduced, then attention is paid to the position of railway transport in the transport of persons and the organisation of railway transport in Slovakia. Main focus is put on the problem of deregulation, liberalisation, and starting competition in passenger railway transport in Slovakia with an example of the operation of a private carrier on the railway line Bratislava - Komárno. The specific phenomenon that influenced railway transport in Slovakia has become a zero-fare public railway transport services for selected groups of passengers and contributed to the growing share of railways in modal split of passenger transport. Conclusion remarks and some future challenges for railway passenger transport are also presented.

\section{BASIC FACTS ABOUT RAILWAY NETWORK IN SLOVAKIA}

The total construction length of operated railway lines in Slovakia in 2016 was $3,579 \mathrm{~km}$ (MDaV SR 2017). The railway network in Slovakia is one of the densest $\left(73.0 \mathrm{~km}\right.$ per $\left.1,000 \mathrm{~km}^{2}\right)$ in Europe, but one of the oldest as well. The railway net- 
work is the result of a more than 150-year development in various natural, economic and political conditions. The natural conditions in the territory of Slovakia (especially mountainous relief) have to a large extent influenced the course of railway lines. Different political conditions in Austria-Hungary, the First Czechoslovak Republic, the Slovak State during the Second World War, in the period of socialism, during the disintegration of Czechoslovakia, the accession of Slovakia to the EU have also played an important role.

According to the study prepared by ECORYS (2006), the technical level of railway infrastructure in Slovakia did not provide sufficient foundations for providing quality services and for joining the international transport market. Therefore, the development of the railway network in Slovakia has been based on a forecast of the future development of transport in Europe and the principles of European transport policy. Modernisation and the development of the railway transport infrastructure have been focused on quality improvement with the modernisation of infrastructure on main corridors and safety and quality of operational improvement.

In Slovakia, there have been efforts to improve railway transport via the modernisation of railway infrastructure (increasing the speed limit to $160 \mathrm{~km} / \mathrm{h}$ ) on the railway lines that are parts of trans-European corridors. Slovakia has three Core Network Corridors crossing the country: the Baltic-Adriatic corridor, the Orient/ East-Med corridor, and the Rhine-Danube corridor (Fig. 1). Modernisation concentrates mainly in the western part of the country on the main Slovak track from Bratislava to Žilina. By the end of 2017, a continuous 157.5-km-long Bratislava-Rača - Púchov track had been adapted for a speed of $160 \mathrm{~km} / \mathrm{h}$. Also, a 19-km section of the main railway track, between Žilina and Krásno nad Kysucou (Tab. 1), had also been upgraded, but this speed is not allowed on the whole section.

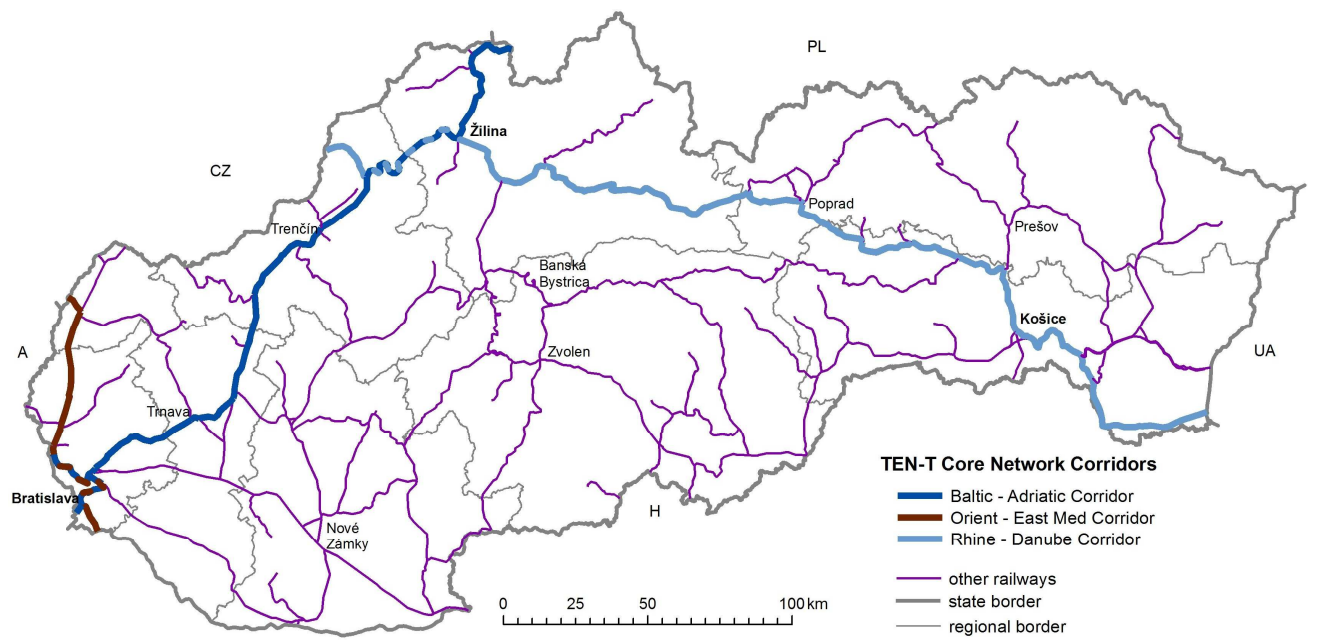

Fig. 1. TEN-T Core Network Corridors in the railway network of Slovakia Source: Michniak (2016). 
Tab 1. Modernisation of railways in Slovakia for the speed of $160 \mathrm{~km} / \mathrm{h}$

\begin{tabular}{lcc}
\hline Railway track & Length $(\mathrm{km})$ & Period \\
\hline Bratislava, Rača -Trnava & 41.6 & $2002-2008$ \\
Trnava - Nové Mesto nad Váhom & 53.0 & $2004-2009$ \\
Žilina - Krásno nad Kysucou* & 12.0 & $2008-2011$ \\
Nové Mesto nad Váhom - Púchov & 62.9 & $2009-2017$ \\
Považská Teplá - Žilina & 22.7 & $2014-2018$ \\
Púchov - Žilina & 38.5 & $2016-2020$ \\
\hline
\end{tabular}

Source: own elaboration based on data from the ZSR.

\section{POSITION OF RAILWAY TRANSPORT IN PASSENGER TRANSPORT IN SLOVAKIA}

Over recent centuries, different transport modes have been crucial accelerators of the development of population mobility. The building of railways in the 19th century led to a growing number of people traveling, and railways became the first mass form of transport (Page 2009). Railway travel was the dominant form of mass public transport before the age of the automobile (Rodrigue et al. 2006). In the 20th century, road transport took the dominant role in the transport of passengers. In the second half of the 20th century, air transport became a global phenomenon responsible for the growth of mobility.

The position of individual transport means in the modal split of passenger transport has changed over time. Public passenger transport had a dominant role in a modal split in former Czechoslovakia and also other socialist countries of Central -Eastern Europe (e.g. Horňák and Pšenka 2013, Horňák et al. 2013). A significant shift in the demand for different types of transport occurred after 1989. The passenger transport has been influenced (similarly as in other countries of the EU) by the very fast increase of the motorisation level in Slovakia from 165 cars per 1,000 inhabitants in 1990 to 236 in 2000 and 307 in 2010. In 2015 it reached 375 cars per 1,000 inhabitants. The role of private cars increased at the expense of public road and railway transport. The same trends were visible also in other post-socialist countries (Howkins 2005 and Pucher and Buehler 2005). The growing importance of individual transport is related to the growth in the flexibility and mobility of the labour force. The growing mobility of society, especially in urban areas, has led to increasing problems with transport congestion.

After 1989, there was an evident decrease of the importance of public transport in Slovakia, especially in road public transport which can be observed in the number of passengers and also in the performance of passenger transport (Fig. 2).

The position of railway transport in the transport of persons in Slovakia worsened until 2005. It was also related to the decline in the demand of railway transport and the closures of passenger transport on several regional tracks with great losses for railway operations. Between 2000 and 2012 passenger transport was discontinued on more than $530 \mathrm{~km}$ of regional railway tracks in Slovakia (Michniak 2016). Then there was a phase of its stabilisation, and during the last few years, the position of railways has improved, especially since 2014 . This posi- 
tive trend is mainly a result of the introduction of the zero-fare public railway transport services for selected groups of passengers.
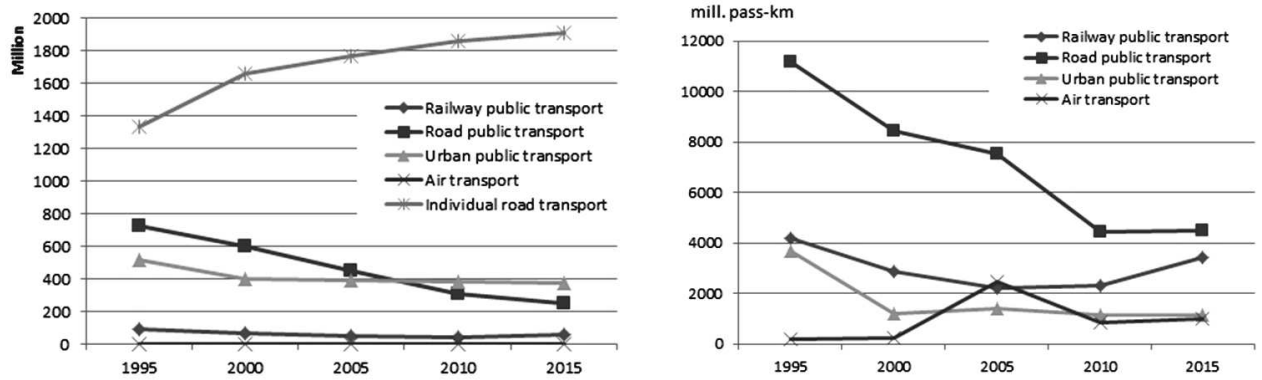

Fig. 2. The position of railway transport in passenger transport in Slovakia $a$ - number of passengers (millions of persons), $b$ - performance of passenger transport (millions of pass-km)

Source: own elaboration based on data MDaV SR (2017).

\section{ORGANISATION OF RAILWAY TRANSPORT IN SLOVAKIA}

The effective functioning of the transport system within the specific territory is an important organisation of transport. The division of the Czechoslovak railway system followed the division of the Czechoslovak Federative Republic. On $1^{\text {st }}$ January 1993 the Czechoslovak State Railways were divided into two separate entities České dráhy (Czech Railways - C C) and Železnice Slovenskej republiky (Railways of the Slovak Republic - ŽSR). ZSR was established by a decree of the Government of the Slovak Republic on the establishment of a state enterprise. The decision of the Government of the Slovak Republic was elaborated by the Act of the National Council of the Slovak Republic no. 258/1993 Coll. on Railways of the Slovak Republic. Since $1^{\text {st }}$ January 2002 the ŽSR has been divided into two separate entities - ŽSR and Železničná spoločnost' (Railway Company - ZSSK) according to the ŽSR Transformation and Restructuring Project. Subsequently, on 1 January 2005, ZSSK was split into the Železničná spoločnost' Slovensko, a.s. providing passenger transport and Cargo Slovakia, a.s. ensuring freight transport (ZSR 2017, http://www.zsr.sk).

Železnice Slovenskej Republiky (ZSR) ensures the management and operation of railway infrastructure in Slovakia. Public railway transport in Slovakia is provided first of all by the state carrier Železničná spoločnost' Slovensko (ZSSK). This division follows the EU decision that infrastructure should be separated from the freight and passenger operations.

The operation of trains of the state carrier ZSSK is based on the Contract on Transport Services in Public Interest concluded by and between the Ministry of Transport of the Slovak Republic and ZSSK. The state orders ZSSK to deliver specific performances for the given year throughout Slovakia (train-km, number and time of trains on specific routes) and at the same time ZSSK determines the fares. Because prices are not market-driven, the state pays, regarding a valid contract, the difference between economically eligible costs and achieved economically eligible returns. In 2017, this difference reached 254 million euros (SITA 2018). In 2016, ZSSK transported 65.5 million passengers (ZSSK 2017). 
In 2017, in addition to the state carrier, there were also three private carriers in passenger railway transport in Slovakia (Fig. 3). The Czech company RegioJet became the first private carrier in passenger railway transport in Slovakia since the end of 2011. It started with one pair of trains in the IC category on a daily basis on the route Prague - Ostrava - Zilina that was later prolonged to Košice. Since March 2012 it has operated on the route Bratislava - Dunajská Streda - Komárno. Since December 2014 it started operating on the main railway route in Slovakia, Bratislava - Žilina - Košice, but this operation stopped in January 2017. Since December 2016 and its trains were relocated to the railway route Bratislava - Brno Prague.

The second private carrier, a Czech company LEO Express started operating on the track Prague - Ostrava - Zilina in December 2014 which was also prolonged to the centres of Eastern Slovakia, Prešov, and Košice.

A third private carrier, Arriva, a part of Deutsche Bahn, started its operations in December 2016 on the route Prague - Trenčín with two pairs of trains during a week. Since March 2016 it has prolonged its operation to Nitra.

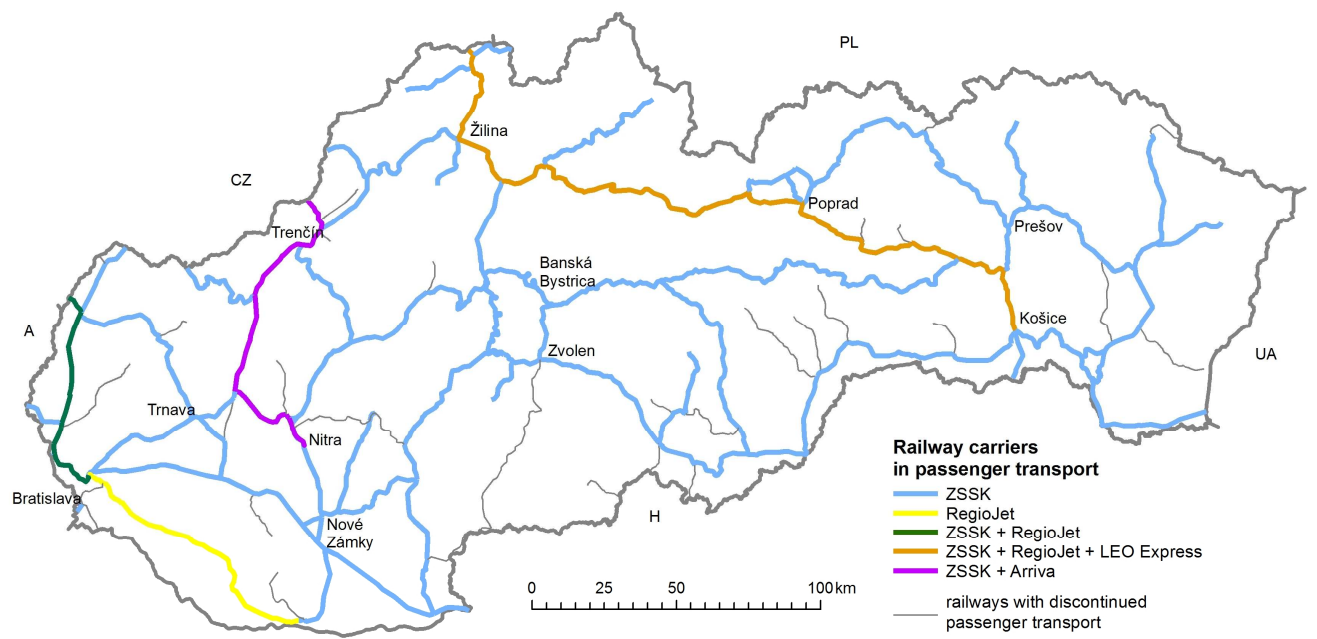

Fig. 3. Railway carriers in passenger railway transport in Slovakia in 2017 Source: own elaboration.

\section{DEREGULATION, LIBERALISATION, AND COMPETITION IN PASSENGER RAILWAY TRANSPORT IN SLOVAKIA}

A target of the European transport policy in the form of a common transport market (freedom of transport services and the opening of transport markets) has been largely achieved, except for railway transport, where the common market has so far only been partially developed. As the EU has decided to separate operations from actual infrastructure, the market entry for new companies is relatively low, as compared to, e.g., the US, where this sector is vertically integrated (Hilmola and Szekely 2006). These authors also proposed normative instructions for the EU member states, which were in the process of taking their first steps in the deregulation process. They recommended that government should stay as the main owner in 
both infrastructure and railway operations since this is the only way that mediumterm thinking is enabled in daily decisions.

The liberalisation of the railway market can be an important instrument for increasing the attractiveness of local rail services and consequently for making the railways more competitive with other means of transport, which could result in changing the modal share in the favour of railways (Taczanowski 2015).

EU member states are in different stages of liberalisation or deregulation of passenger transport markets. According to the European Commission (2013), the UK, Germany, Sweden, Italy, Austria, Slovakia and Czechia are the European countries with an operating open access service. The open access entries in the UK, Germany, and Sweden have been focused on neglected market segments and usually competition based on lower prices/lower quality strategy (Fröid and Nelldal 2015 and Eriksson and Pettersson 2012). Open access entries in Austria, Italy, Slovakia and Czechia have varied, and new carriers have focused on main railway tracks with the highest density passenger flows in the country (Tomeš et al. 2014 and 2016, Bergantino et al. 2015 and Jade et al. 2015).

In Czechia, open-access competition in the passenger railway sector already started in 2011 on the Prague - Ostrava route where the three major operators include the national operator, České dráhy (ČD), and two private players, RegioJet since 2011 and LEO Express since 2013 (Jade et al. 2015). According to Tomeš et al. 2016, open access on the Prague - Ostrava route is evolving with rate declines and service improvements, but all of the competitors are operating at a loss, and open-access competition has increased congestion on this main railway artery.

In Poland partial deregulation of public transport has been in effect since 2000 . Four companies within the PKP Group were established to provide passenger services: Warsaw Commuting Rail (WKD) and Fast Urban Rail (SKM) - both operating on separate segments of the track - as well as PKP Intercity and PKP Regional Carriages (Przewozy Regionalne). As each company operated in a different sector of the market, there was no real competition among them in practice (Taylor and Ciechański 2006).

In Slovakia, direct competition between national and private carriers started in December 2014 on the route Bratislava - Žilina - Košice. During one year of the open access competition, there was a price war between the carriers ZSSK and RegioJet, but it had been influenced by the introduction of the zero-fare public railway transport services for selected groups of passengers. Competition has led to the improvement of the quality of traveling for passengers in the form of additional services as refreshment, Wi-Fi connection to the Internet and others. On 18th January 2016, ZSSK stopped the operation of IC trains due to long-term losses. After the change of government in 2016, an operation of IC trains was restored in December 2016. RegioJet stopped operating on the route Bratislava - Košice in January 2017. The reason for this decision was financial loss because selected groups of passengers preferred zero-fare public railway transport services in the trains of the state carrier ZSSK to the detriment of traveling in the trains of the private carrier. RegioJet moved its trains on the route Bratislava - Prague where it started operating in December 2016.

The long-distance route Bratislava - Banská Bystrica was selected by the Ministry of Transport of the Slovak Republic as the first route for the liberalisation of rail services. In November 2015, the competition for the operation on this line was 
announced with the aim of improving the services provided and to make railway transport more efficient. However, in February 2017 this competition was canceled. The first tenders for the operation of trains for passenger transport on railway routes can be expected only in 2019 . There is a list of 35 railway lines where passenger transport should be liberalised (Ragáčová 2018).

\section{PASSENGER TRANSPORT ON THE RAILWAY LINE BRATISLAVA - DUNAJSKÁ STREDA - KOMÁRNO}

The railway route Bratislava - Dunajská Streda - Komárno is a regional railway in the hinterland of Bratislava (see Fig. 1) with intensive commuting flows to the capital city of Slovakia. Operation on the route Bratislava - Komárno was provided by the national carrier (ZSSK) until $3^{\text {rd }}$ March 2012, when it ran 13 pairs of trains a day. There was no stable interval in departure times. There were 790,000 passengers transported in 2011.

The private carrier RegioJet took over operation on this line on $4^{\text {th }}$ March 2012. The operation of trains of the private carrier on this line is based on the Contract on Transport Services in Public Interest concluded by and between the Ministry of Transport of the Slovak Republic and RegioJet and is valid until December 2020. In 2017, RegioJet obtained 8.44 million euros from the state for operation on this route.

Before the start of RegioJet operations, ZSR reconstructed railway tracks, and RegioJet invested in railway stations and parking at railway stations. The new carrier has improved services for passengers (refreshment, Wi-Fi internet) and introduced a tact timetable.

Since 2012 the number of passengers on the route has grown more than three times (see Fig. 4). The growing number of passengers has also brought problems with the overcrowding of trains and often a delay of trains. The number of passengers on this line has the potential for further growth in the future. This line is only single track railway, but it would be desirable to upgrade it to a double track railway. In 2018 it should be included in the integrated transport system of Bratislava region. There are plans for new stops and new parking that could ensure better accessibility for passengers traveling to Bratislava from its suburban zone.

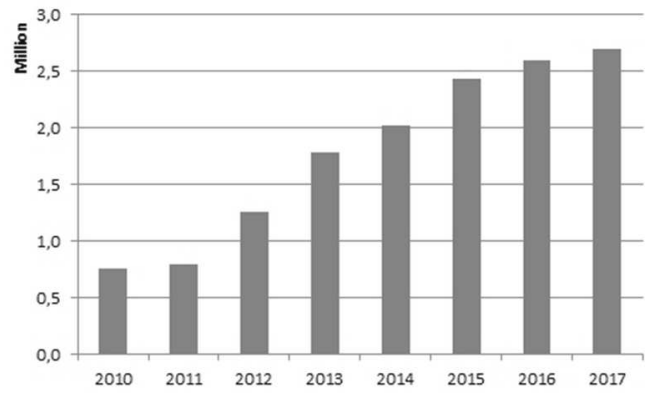

Fig. 4. Number of passengers on the route Bratislava-Komárno Source: RegioJet (2018). 


\section{ZERO-FARE PUBLIC RAILWAY TRANSPORT SERVICES FOR SELECTED GROUPS OF PASSENGERS}

According to van Goeverden et al. (2006), the pricing of public transport may range from charging the full price to supplying it for free. The present situation in most European countries is between the two extremes implying a partial cost recovery. Zero-fare or free public transport is public transport where all costs for transport are funded by governments at different levels (national, regional or local) or by private companies. Some European cities converted their whole public transport networks to the zero-fare system. In Tallinn, the capital city of Estonia, public transport for citizens registered to live in Tallinn has been free since $1^{\text {st }} \mathrm{Ja}$ nuary 2013 (Tallinn 2018). The Belgian city Hasselt introduced free public transport on $1^{\text {st }}$ July 1997 , which led to the rapid growth of the number of passengers, but due to financial reasons, Hasselt canceled free public transport in 2013 (Canters 2014). In some cases, only particular groups of inhabitants are exempted from fares.

The zero-fare public railway transport services have been valid on the trains of the state carrier Železničná spoločnost' Slovensko, a.s. (ZSSK) and on the Bratislava - Komárno line of the private carrier RegioJet since $17^{\text {th }}$ November 2014 (the Day of Struggle for Freedom and Democracy - a public holiday in Slovakia). This form of state support benefits all children under 15 years of age and seniors over 62 without limitation of their citizenship or residence, as well as students and seniors under 62 who are citizens or permanent residents of the EU member states. There are some limitations of this measure. Passengers entitled to zero-fare transport services are required to register at ZSSK cash desks. Upon registration, they obtain railway customer cards that allows them to get zero-fare tickets for traveling by trains. Zero-fare tickets are passenger-specific, i.e., the tickets are non-transferable to other persons Zero-fare tickets are not valid in the IC category of trains.

By the end of 2017, 1.125 million passengers were registered for zero-fare transport, and only $3.8 \%$ of them were passengers from other countries especially from Czechia (ZSSK 2018). Seniors over 62 and students in the age range 15-26 dominated in the structure of registered persons for zero-fare railway transport by the end of 2017 (Fig. 5). In the structure of zero-fare passengers during 2017 (ZSSK 2018) students dominated in the age range 15-26 (59\%), followed by seniors over 62 years $(19 \%)$, seniors under 62 years $(12 \%)$ and children or students under 15 years $(10 \%)$. It means that students in the age range 15-26 use zero-fare rail transport often than seniors.

More than 126.5 million passengers used free transport a year until the end of 2017 (Fig. 6). The share of the zero-fare passengers in the total number of ZSSK passengers decreased gradually from $43 \%$ in 2015 to $37 \%$ in 2017 . The growth of the number of paying passengers was partially caused by the withdrawal of the RegioJet from the main railway track Bratislava - Žilina but railways also attracted passengers in the suburban regions of Bratislava and other bigger towns.

The zero-fare policy can be regarded as a response of ZSSK to the direct competition with RegioJet since December 2014. It is a political rather than an expert decision, and it costs at least 13 million euros a year (MDVaRR SR 2016). Not all regions and their inhabitants can benefit from this service because it is not accessible in all regions of Slovakia (see e.g. Michniak 2006). 
On the other hand, this policy can also have positive effects, and it can contribute to an increase in the number of travellers for tourism.
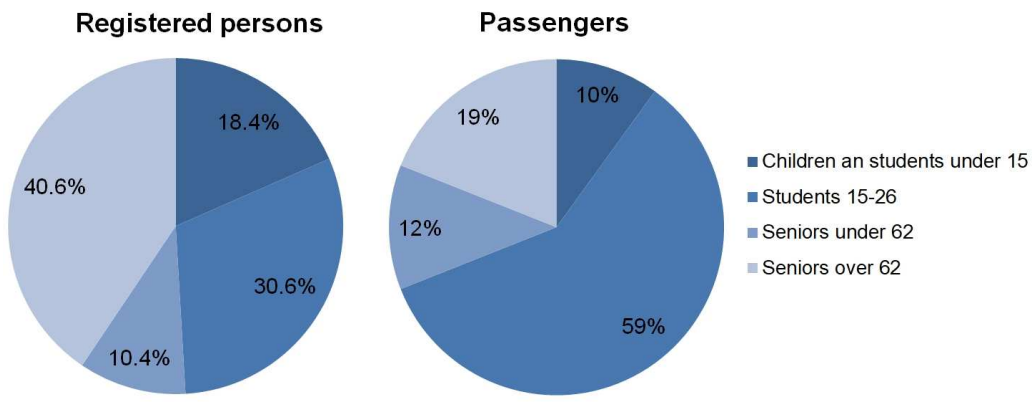

Fig. 5. Zero-fare railway transport in Slovakia

a - structure of registered persons by the end of $2017, b$ - structure of passengers that used zero-fare policy in 2017

Source: Own elaboration based on data from the ZSSK (2018).

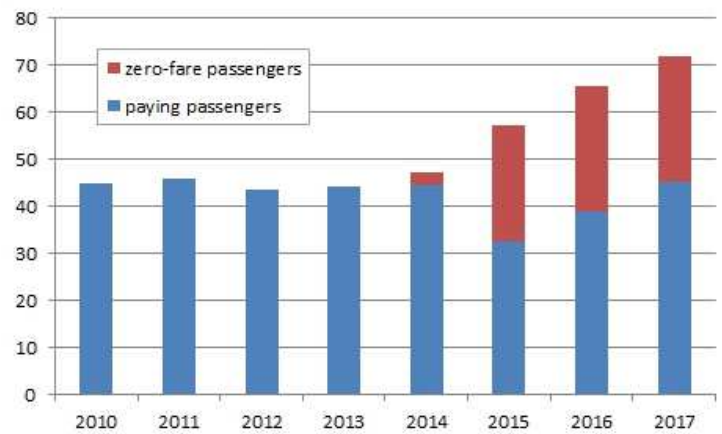

Fig. 6. Number of passengers (million) of the state carrier in the period 2010-2017

Source: Own elaboration based on data from the ZSSK (2018).

\section{CONCLUSIONS}

There is a close relationship between spatial organisation of society as a whole and spatial organisation of transport what can be documented by previous studies concerning railways in Slovakia (e.g. Podhorský 1976, Řehák 1992, Székely 2004, Michniak 2006 and 2016 and Horňák and Pšenka 2013). The organisation of public rail transport should reflect changes in settlement system (e. g. suburbanisation in the hinterland of the largest cities and towns) changes in economic positions of centres (e.g. development of new centres with investments to industry, tourism, and other services).

The accession process to the EU and EU membership since 2004 have been the most decisive factors which have influenced the transport policy of Slovakia during the last two decades. They have manifested themselves in the modernisation of railway tracks included in the TEN-T corridors, in new trains for regional and suburban railways with the aim of the improvement of the quality of railway passenger transport in Slovakia. 
Before 1989, public passenger transport had a dominant role in the modal split of passenger transport in the former Czechoslovakia and also in other socialist countries of Central-Eastern Europe. After 1989, there was an evident decrease in the importance of public transport and the development of individual automobile transport. The position of railway transport in the transport of persons in Slovakia worsened until 2005. Then there was a phase of stabilisation of railways in the modal split. The negative influence for transport in many regions of Slovakia has been caused by the closures of passenger transport on several regional tracks. A significant increase of the railway transport performance since 2014 has been achieved mainly through the introduction of the zero-fare railway transport for certain groups of passengers. Growing number of passengers on railways can be on of the reasons for starting discussion about the reactivation of regional railway tracks where passenger transport was discontinued between 2000 and 2012.

The state carrier ZSSK has a dominant role in passenger transport in Slovakia. It operates passenger transport in the whole territory of Slovakia on tracks of international, national and regional importance. It is well known that passenger transport is in majority cases not profitable and most often supported by governments. The ZSSK operates railway transport mainly on the base of contracts with the state. In 2017, there were also three other private carriers in Slovakia that were focused on long-distance connections to Prague. The regional track Bratislava Dunajská Streda - Komárno is an exception because it was operated only by the private carrier on the base of a contract with the state. Passenger transport on the railway line Bratislava - Dunajská Streda - Komárno is an example of the better organisation of railway transport by the private carrier in comparison to the state carrier. State carrier could not use the potential of this track and attract passengers from road transport to the railway. Traffic congestions in the eastern/south-eastern part of the suburban zone of Bratislava also contributed to the success of the private carrier.

It is difficult to assess the potential consequences of deregulation in the railway sector in Slovakia at present. Direct competition in railway passenger transport in Slovakia started in 2014, but till 2018 it was functioning only to a limited extent. Zero-fare public transport contributed to the deformation of the market in passenger railway transport. Slovakia has become a not perspective country for the commercial development of passenger railway transport. State interventions threaten further liberalisation of the transport market in passenger railway transport, and it is still one of the main challenges of passenger railway transport in Slovakia. First tenders for the operation of trains for passenger transport on railway routes can be expected only in 2019. There is a list of 35 railway lines in Slovakia where passenger transport should be liberalised.

Another challenge is including railways to the integrated transport systems of regions of the largest cities and towns in Slovakia. While bus transport is in the competence of 8 self-government regions, railways are still in the competence of the state. The integrated transport system in Slovakia is developing in the Bratislava region. The functioning of the Integrated Transport System of the SouthMoravian Region can serve as a good example of the integration of regional transport (see Št'astná et al. 2015) in post-socialist countries. Various aspects of integrated transport are discussed in the book by Givoni and Banister (2010). 
Discussions concerning high-speed railways is limited in Slovakia because there is weak population potential for high-speed railways in the majority of Slovak regions. Only Bratislava in the proximity of Vienna $(65 \mathrm{~km})$ could be included to such plans in the near future. There are also other visions of development of public transport such as a Hyperloop between Bratislava and Vienna (see Smith 2016 and Taylor et al. 2016).

This work was supported by the VEGA Grant Agency under the project No. 2/0095/18.

\section{REFERENCES}

BERGANTINO, A. S., CAPOZZA, C., CAPURSO, M. (2015). The impact of open access on intra- and inter-modal rail competition. A national level analysis in Italy. Transportation Policy, 39, 77-86.

CANTERS, R. (2014). Hasselt cancels free public transport after 16 years (Belgium), [Online]. Available: http://www.eltis.org/discover/news/hasselt-cancels-free-publictransport-after-16-years-belgium-0/ [accessed 8 June 2018].

ECORYS (2006). Study on strategic evaluation on transport investment priorities under structural and cohesion funds for the programming period 2007 - 2013. Rotterdam (ECORYS Nederland BV).

ERIKSSON, M., PETTERSSON, T. (2012). Adapting to liberalization: government procurement of interregional passenger transports in Sweden 1989-2008. Journal of Transport Geography, 24, 182-188.

European Commission (2001). White Paper "European Transport Policy for 2010 - Time to Decide”. Brussels (European Commission).

European Commission (2011). White Paper "Roadmap to a Single European Transport Area - Towards a competitive and resource efficient transport system". Brussels (European Commission).

European Commission (2013). Proposal for a Regulation of the European Parliament and of the Council amending Regulation (EC) No 1370/2007 concerning the opening of the market for domestic passenger transport services by rail. Impact Assessment. Brussels (European Commission).

FRÖID, O., NELLDAL, B. (2015). The impact of market opening on the supply of interregional train services. Journal of Transport Geography, 46, 189-200.

GIVONI, M., BANISTER, D. (2010). Integrated transport. From policy to practice. London (Routledge).

HALL, D. R. (1993). Impacts of economic and political transition on the transport geography of Central and Eastern Europe. Journal of Transport Geography, 1, 20-35.

HILMOLA, O.-P., SZEKELY, B. (2006). Deregulation of railroads and future development scenarios in Europe - literature analysis of privatization process taken place in US, UK and Sweden, Research Report 169. Lappeenranta (Lappeenranta University of Techno$\log$ ).

HORNAK, M., PŠENKA, T. (2013). Verejná doprava ako indikátor medzisídelných väzieb medzi mestami Slovenska. Geografický časopis, 65, 119-140.

HORŇÁK, M., PŚENKA, T., KRIŽAN, F. (2013). The competitiveness of the longdistance public transportation system in Slovakia. Moravian Geographical Reports, 21 (4), 64-75.

HOWKINS, T. J. (2005). Changing hegemonies and new external pressures: South East European railway networks in transition. Journal of Transport Geography, 13, 187-197.

JADE, R., MOLKOVÁ, T., KVIZDA, M. (2015). Role of railways in empowering travelers: a case study from the Czech Republic. Journal of Rail Transport Planning \& Management, 5, 31-49. 
MDaV SR (2017). Ministry of transport and construction of the Slovak Republic, [Online]. Available: http://www.telecom.gov.sk/ [accessed 25 August 2017].

MDVaRR SR (2016). Ministry of transport, construction and regional development of the Slovak Republic, [Online]. Available: http://www.telecom.gov.sk/ [accessed 18 July 2016].

MPaRV SR (2010). National regional development strategy of the Slovak Republic 2010. Bratislava (Ministry of Agriculture and Rural Development of the Slovak Republic).

MICHNIAK, D. (2006). Accessibility of the railway network in Slovakia. Europa XXI, 15, 51-61.

MICHNIAK, D. (2016). Role of railway transport in tourism: Selected problems and examples in Slovakia, Quaestiones Geographicae, 35, 107-120.

PAGE, S. J. (2009). Transport and tourism global perspectives. Harlow (Prentice Hall), London (Pearson).

PODHORSKÝ, F. (1976). Niektoré geografické črty železničnej dopravy v Západoslovenskom kraji. Geografický časopis, 28, 37-57.

PUCHER, J., BUEHLER, R. (2005). Transport policies in Central and Eastern Europe. New Brunswick NJ (Rutgers University).

RAGÁČOVÁ, K. (2018). Prečo k nám súkromné vlaky tak skoro neprídu. Trend, 25.1.2018, [Online]. Available: https://www.etrend.sk [accessed 25 January 2018].

REGIOJET (2018). Informácie o počte cestujúcich poskytnuté 2. 2. 2018. Bratislava (RegioJet).

RODRIGUE, J.-P., COMTOIS, C., SLACK, B. (2006). The geography of transport systems. London, New York (Routledge).

ŘEHÁK, S. (1992). Sídelně dopravní model ČSFR a jeho územní souvislosti. Geografický časopis, 44, 59-72.

SITA (2018). Železničná spoločnost' má dostat’ od štátu 254 miliónov eur, [Online]. Available: http://www.sita.sk/ [accessed 4 January 2018].

SMITH, D. (2016). The fifth mode. Construction Research and Innovation, 7, 12-15.

SZÉKELY, V. (2004). Priame dopravné prepojenia okresných miest Slovenska. Prace komisji geografii komunikacji PTG, 10, 281-302.

ŠŤASTNÁ, M., VAISHAR, A., STONAWSKÁ, K. (2015). Integrated transport system of the South-Moravian region and its impact on rural development. Transportation Research Part D: Transport and Environment, 36, 53-64.

TACZANOWSKI, J. (2015). The effects of liberalisation of the passenger railway market on the situation of regional rail connections in Poland, Czech Republic, Slovakia and Austria. Review of Economic Perspectives - Národohospodářský obzor, 15, 249-268.

TALLINN (2018). The right of free travel and documents evidencing the right, [Online]. Available: https://www.tallinn.ee/eng/pilet/The-Right-of-Free-Travel [accessed 8 June 2018].

TAYLOR, C. L., HYDE, D. J., BARR, L. C. (2016). Hyperloop commercial feasibility analysis: high level overview. Cambridge (U.S. Department of Transportation John A. Volpe National Transportation Systems Center).

TAYLOR, Z., CIECHANSKI, A. (2006). Deregulation in Polish rail transport. Transport Reviews: A Transnational Transdisciplinary Journal, 26, 305-324.

TOMEŠ, Z., KVIZDA. M., JANDOVÁ, M., REDERER, V. (2016). Open access passenger rail competition in the Czech Republic. Transport Policy, 47, 203-211

TOMEŠ, Z., KVIZDA, M., SEIDENGLANZ, D., NIGRIN, T. (2014). Competition in the passenger railway market in the Czech Republic. Research in Transportation Economics, 48, 270-276.

Van GOEVERDEN, C., RIETVELD, P., KOELEMEIJER, J., PEETERS, P. (2006). Subsidies in public transport. European Transport, 32, 5-25.

ZSR (2017). Železnice Slovenskej republiky, [Online]. Available: http://www.zsr.sk, [accessed 1 December 2017].

ZSSK (2017). Železničná spoločnost' Slovensko, [Online]. Available: http:// www.slovakrail.sk/ [accessed 1 December 2017]. 
ZSSK (2018). Informácie o bezplatnej doprave poskytnuté ZSSK 22. 1. 2018. Bratislava (Železničná spoločnost' Slovensko).

Daniel Michniak

\section{ZMENY, PROBLÉMY A VÝZVY OSOBNEJ ŽELEZNIČNEJ DOPRAVY NA SLOVENSKU}

Systém osobnej železničnej dopravy na Slovensku za posledných takmer tridsat' rokov prešiel viacerými zmenami a čelil mnohým problémom a novým výzvam. Dopravný systém na Slovensku ovplyvnili napr. zmena sociálno-ekonomického systému, rozdelenie Ceskoslovenska, prístupový proces do EÚ a členstvo v EÚ. Hlavným ciel'om tohto článku je identifikovat' vybrané zmeny, problémy a výzvy osobnej železničnej dopravy na Slovensku po roku 1989. Pozornost' je venovaná meniacemu sa postaveniu železničnej dopravy v preprave osôb na Slovensku, zmenám v organizácii železničnej dopravy na Slovensku a jej deregulácii, liberalizácii a konkurencii v osobnej železničnej doprave a taktiež aj bezplatnej preprave pre vybrané skupiny cestujúcich zavedenej v roku 2014.

Pred rokom 1989 dominovala v preprave osôb v bývalom Československu, ako aj v ostatných socialistických krajinách strednej a východnej Európy verejná osobná doprava. Po roku 1989 došlo k výraznému poklesu významu verejnej dopravy a rozvoju individuálnej automobilovej dopravy. Pozícia železničnej dopravy v preprave osôb na Slovensku sa zhoršovala až do roku 2005, neskôr nastala fáza stabilizácie pozície železníc v rámci modálneho rozdelenia. Negatívny vplyv na dopravu $\mathrm{v}$ mnohých regiónoch Slovenska malo zastavenie osobnej dopravy na viacerých regionálnych tratiach. Značný nárast výkonu železničnej dopravy od roku 2014 bol dosiahnutý najmä zavedením bezplatnej železničnej dopravy pre vybrané skupiny cestujúcich.

Dominantnú úlohu v osobnej doprave na Slovensku má štátny dopravca ZSSK. Prevádzkuje osobnú dopravu na celom území Slovenska na tratiach medzinárodného, národného a regionálneho významu. Osobná železničná doprava nie je vo väčšine prípadov zisková a najčastejšie býva podporovaná štátom. ZSSK prevádzkuje osobnú železničnú dopravu na základe zmluvy so štátom. V roku 2017 pôsobili na Slovensku aj traja d’alší súkromní dopravcovia orientovaní najmä na dial'kové spoje do Prahy. Regionálna trat' Bratislava - Dunajská Streda - Komárno je výnimkou, pretože od roku 2012 je prevádzkovaná len súkromným dopravcom na základe zmluvy so štátom. Preprava cestujúcich na spomínanej železničnej trati je príkladom lepšej organizácie železničnej dopravy súkromným dopravcom v porovnaní so štátnym, ktorý nedokázal využit potenciál tejto trasy a prilákat' cestujúcich z cestnej dopravy na železničnú. Dopravné zápchy v juhovýchodnej časti suburbánnej zóny Bratislavy tiež prispeli až k trojnásobnému rastu počtu cestujúcich.

Nie je jednoduché posúdit' potenciálne následky prebiehajúcej deregulácie v železničnom sektore na Slovensku. Priama konkurencia v železničnej osobnej doprave na Slovensku začala $\mathrm{v}$ roku 2014, ale do roku 2018 fungovala len v obmedzenom rozsahu. K deformácii trhu železničnej osobnej dopravy prispela bezplatná železničná doprava. Slovensko sa stalo nevýhodnou krajinou $\mathrm{z}$ hl'adiska komerčného rozvoja osobnej železničnej dopravy. Zásahy štátu ohrozujú d’alšiu liberalizáciu dopravného trhu v osobnej železničnej doprave, ktorá je nad’alej jednou z hlavných výziev osobnej železničnej dopravy na Slovensku. Prvé sút'aže na prevádzku osobnej železničnej dopravy na vybraných tratiach možno očakávat' až v roku 2019. Ďalšou výzvou osobnej železničnej dopravy na Slovensku je jej zapojenie do integrovaných dopravných systémov najväčších miest a v d'alších regiónoch Slovenska, ktorý sa zatial' najlepšie rozvíja v Bratislavskom kraji. 